\title{
Relationship of initial seed borne infection of Colletotrichum corchori and jute seed yield parameters under greenhouse
}

\author{
M. S. Alam $^{a}$ and M. M. Islam ${ }^{b}$ \\ a Dept. of Agriculture Extension, Ministry of Agriculture, Dhaka, Bangladesh \\ ${ }^{b}$ Pest Management Division, Bnagladesh Jute Research Institute (BJRI), Dhaka, Bangladesh
}

\begin{abstract}
The study was under taken to make an acquisition of knowledge on the relationship of initial seed borne infection of Colletotrichum corchori and jute seed yield parameters under Greenhouse condition. Experiment was conducted at Plant Pathology Department and Greenhouse of Bangladesh Jute Research Institute (BJRI) during July 2011 to April 2012. All together 600 (six hundred) jute seed samples were collected from different sources and categorized as $0.0 \%, 5 \% .10 \%, 15 \%, 20 \%$ and $25 \%$ initial of pure seed borne infection with $C$. corchori for further study. Germination of the seed varied significantly and decreased with the increase initial seed borne infection of C. corchori. Germination failure/dead seed, infected seedlings and total dead seed varied significantly and increased with the increase of initial seed borne infection of $C$. corchori. There were negative relationships between, seed yield parameters of the harvested seeds of CVL-1 produced in Greenhouse with initial seed borne infection of C. corchori. The regression coefficients for germination, plants/pot, seeds/pod and seeds/plant were $-1.048,-0.403,-0.756$ and -34.24 , respectively. On other hand, relationship of infected seedlings and total dead seeds in Greenhouse were positive with the initial seed borne infections of $C$. corchori and the regression coefficients for infected seedlings and total dead seed were 0.248 and 0.751 , respectively. Since, anthracnose of jute caused by fungus Colletotrichum corchori is a seed borne disease and transmit from seed to plant to seed and consequently hamper the quality and yield of fibre and affect the seed quality and seed yield as well and thus necessary precautions should be taken before sowing and after germination of the seeds to produce higher yield and quality jute seed and fibre.
\end{abstract}

Key words: Initial seed borne infection, Colletotrichum corchori, Seed yield parameter and Greenhouse

Please cite this article as: Alam, M. S. and Islam, M. M. (2015). Relationship of initial seed borne infection of Colletotrichum corchori and jute seed yield parameters under Greenhouse. Journal of Bioscience and Agriculture Research 04(01): 31-39.

This article is distributed under terms of a Creative Common Attribution 4.0 International License

\section{Introduction}

Jute (Corchorus capsularis L. and Corchorus olitorius L.) is the main cash crop of Bangladesh. It also cultivated in some other countries of the world. It is reported that about $90 \%$ of world's jute is produced in Bangladesh and India (Atwal, 1976). In respect to the production, Bangladesh ranks first among the jute growing countries of the world (Wikipedia, 2011). The export volume of raw jute was increased by $8.17 \%$ as compared to previous year of $2010-11$ whereas the export price gone down by 
$28.06 \%$ and thus Bangladesh as a leader in the jute market in the world should pay proper attention to boost up the production (Ferdous, 2013). Jute suffers from 13 different diseases of which 10 are seed borne (Fakir, 2000). Except leaf mosaic of jute, all seed borne diseases are caused by fungi. Moreover, among the seed borne fungal diseases, anthracnose caused by Colletotrichum corchori (Ikata and Yoshida, 1940) is one of the most important disease of jute. Seedling blight and pre-emergence death of seedlings caused by anthracnose results the yield gaps in the field (Ahmed, 1966). In mature stage, the plant do not die but the disease badly affects the fibre quality. The market value of the fibre was found to be reduced by 30 to $50 \%$ than that of healthy plants as reported by Khan and Strange (1975). The disease is more common in Corchorus capsularis and immune in Corchorus olitorius (Alam et. al., 1992). The seed-borne association of the pathogen was also reported by many scientists (Fakir et al., 1990; Fakir et al., 1991; Haider et al., 1992). Keeping the view of above ideas the present study was under taken to observe the relationship of initial seed borne infection of Colletotrichum corchori with different jute seed yield parameters under Greenhouse condition.

\section{Materials and Methods}

The experiments were conducted in Laboratory and Greenhouse of Plant Pathology Department (PPD), Bangladesh Jute Research Institute (BJRI), during the period from July 2011 to April 2012. The variety CVL-1 belonging to local jute (deshi pat) (Corchorus capsularis) was used for conducting the experiments.

Altogether 600 seed samples were collected from different locations of Bangladesh out of which were 15 breeders, 5 foundations, 7 certified, 570 farmers seed samples and 3 from Seed Companies. Breeder seed samples were collected from Faridpur, Kishorgonj, Manikgonj, Rangpur Regional Stations of BJRI, Monirampur and Patuakhali Sub-station of BJRI. Foundation seeds were collected from 2 locations, Nashipur and Chitla seed production centre of BADC. There were 7 sample of certified seeds collected from 6 seed production zones of BADC, viz. Bogra, Dhaka, Jessore, Kushtia, Rajshahi and Tangail. A total of 570 farmers' seed samples collected from 21 locations of Bangladesh, viz. Chandina, Dhaka, Dinajpur, Gazipur, Jessore, Karimgonj, Karimpur, Kishorgonj, Kushtia, Kurigram, Manikgonj, Meherpur, Monirampur, Nasipur, Pakhimara, Poba, Patuakhali, Rangpur, Saturia, Tangail, Tarabo and 3 from seed companies viz. Rajib, Shamrat and Chand seed companies.

Seed samples were collected from the seed lots of each tie following the rules of ISTA (ISTA, 1999). The collected 600 seed samples of CVL-1 were subjected to germination and health test following blotter method following the International Rules for Seed Health Testing (ISTA, 1999). In this method, $9 \mathrm{~cm}$ diameter plastic petridish and Whatman no. 1 filter paper were used. Two hundred seeds were taken randomly and placed on the moist filter paper in eight petridishes. The petridishes with seeds were then incubated at $22 \pm 20^{\circ} \mathrm{C}$ for 10 days in the laboratory. After incubation, the seeds were examined under stereomicroscope and the fungal pathogens were identified to species level following the keys of Ellis (1993); Mathur and Kongsdal (2003) and expressed as percentage of seeds infected by the pathogens.

Collected seed samples from all seed tiers were categorized on the basis of presence of Colletotrichum corchori as follows for conducting further experiment.

$\mathrm{T}_{0}=0.0 \%$ initial seed borne infection with $C$. corchori

$\mathrm{T}_{1}=5.0 \%$ initial seed borne infection with $C$. corchori

$\mathrm{T}_{2}=10.0 \%$ initial seed borne infection with $C$. corchori

$\mathrm{T}_{3}=15.0 \%$ initial seed borne infection with $C$. corchori

$\mathrm{T}_{4}=20.0 \%$ initial seed borne infection with $C$. corchori

$\mathrm{T}_{5}=25.0 \%$ initial seed borne infection with $C$. corchori

Experiments were set in the Greenhouse at the Central Research Station of BJRI using the jute variety CVL-1 with selected levels of seed borne infections of $C$. corchori. Sixteen inch diameter earthen pots were used for the experiments. Soils collected from the jute fields were sterilized with 4\% Formaldehyde solution @ 200ml/cft of soil. After sterilization, the soils were covered with a polythene sheet for 48 hours. Then the soils were uncovered and kept for 7 days on the sterilized floor of the 
green house with periodic stirring so that the toxic formalin vapor gets evaporated. Then sterilized soil was used for the pot experiments.

Different levels of seed borne infections with C. corchori viz. $0.0 \%, 5.0 \%, 10.0 \%, 15.0 \%, 20.0 \%$, and $25.0 \%$ were used for conducting the experiments. Twenty five seeds were sown in each pot. Thus, altogether 200 seeds were sown in eight pots for each treatment. Two chambers of the green house were used for the experiments. To maintain the sterile condition inside the green house, necessary precautions viz. separate glasshouse was used and pre washed with $4 \%$ formaldehyde solution, pots were kept inside the separate glass house, no other seeds or any equipment was kept inside of that glasshouse. Data were recorded as and when necessary. The experiments were conducted using Completely Randomized Design (CRD).

Data collected from laboratory and Greenhouse experiments were analyzed following Completely Randomized Design (CRD). Mean comparison among the treatments were compared by Duncan's Multiple Range Test (DMRT). Relationships were measured using regression equations (Gomez and Gomez, 1984).

\section{Results and Discussion}

\section{Effect of initial seed borne infection of Colletotrichum corchori on jute seed yield parameters}

Findings of Table 01 reveal that germination varied significantly and decreases with the increase of initial seed borne infection of $C$. corchori. Seed rot/pre emergence death, and post emergence death varied significantly and increases with the increase initial seed borne infection of $C$. corchori. The highest germination (98.0\%) was recorded in case of $\mathrm{T}_{0}$ followed by $93.50 \%$ germination in case of $\mathrm{T}_{1}$. The lowest germination $(70.00 \%)$ was recorded in $\mathrm{T}_{5}$. The seed rot/pre-emergence death and post emergence death due to $C$. corchori increased with the increase of initial seed borne infection of $C$. corchori. Findings of Table 02 evident that germination failure/dead seed, infected seedlings and total dead seed varied significantly and increased with the increase of initial seed borne infection of $C$. corchori. The lowest dead seed (2.0\%) was recorded in $\mathrm{T}_{0}$ and the highest dead (5.0\%) were recorded in $\mathrm{T}_{5}$. The lowest percent infected seedlings $(0.0 \%)$ and the highest infected seedlings $(7.0 \%)$ were recorded in $\mathrm{T}_{0}$ and $\mathrm{T}_{5}$, respectively. The highest total dead seed (Pre and Post emergence) (18.0\%) was recorded in pots sown with $\mathrm{T}_{5}$ followed by $16.33 \%$ where $\mathrm{T}_{4}$ was used. Haque et al. (1999) reported that negative relationship between germination and initial total seed borne fungal pathogens was observed and as there was increase of initial seed borne fungal infections found there was lower seed germination which is in harmony with the present findings.

Findings from Table 03 and 04 showed that seed yield parameters in Greenhouse viz. plants/pot, pods/pot, pods/plant, seeds/pod and seeds/plant varied significantly and decreased with the increase of initial seed borne infection. The highest number of plants/pot (24.25), number of pods/pot (704.50) and number of pods/plant (29.70) were recorded in $\mathrm{T}_{0}$. The lowest number of plants/pot (14.33), number of pods/pot (293.25) and number of pods/plant (18.41) were recorded in case of pots with $\mathrm{T}_{5}$. The highest number of seeds/pod (45.58) and number of seeds/plant (1323.22) were recorded in $\mathrm{T}_{0}$. The lowest number seeds/pod (25.81) and number of seeds/plant (472.53) were recorded in case of pots containing $\mathrm{T}_{5}$. Islam (2006) reported that the reduction of seed yield might be due to the major diseases of jute (anthracnose, black band, stem rot) causing death of seedlings, spread of diseases to standing crops, killing even matured plants. The loss in yield and quality of fibre and seed yield due to major diseases of jute has also been reported by others (Biswas et al., 1985) which supports the present findings.

Findings of Table 05 reveal that seed borne infection with $C$. corchori increased with the increase of initial seed borne infection of $C$. corchori. The lowest seed borne infection with $C$. corchori $(0.0 \%)$ was recorded in $\mathrm{T}_{0}$ and the highest seed borne with $C$. corchori $(22.00 \%)$ recorded in $\mathrm{T}_{5}$ treatment. Islam et al. (2003) reported that initial seed borne infection of fungal pathogens cause less seedling emergence in the field with the increase of initial seed borne infections which is in agreement with the present findings. 
Table 01. Effect of initial seed borne infection of Colletotrichum corchori on germination, Seed rot/pre-emergence and post-emergence death of CVL-1

\begin{tabular}{cccc}
\hline $\begin{array}{c}\text { Initial seed borne } \\
\text { infection of C. corchori }\end{array}$ & $\begin{array}{c}\% \\
\text { Germination }\end{array}$ & $\begin{array}{c}\text { \% Seed rot/pre emergence } \\
\text { death due to C. corchori }\end{array}$ & $\begin{array}{c}\text { \% Post emergence } \\
\text { death due to C. corchori }\end{array}$ \\
\hline $\mathrm{T}_{0}=0.00 \%$ & $98.0 \mathrm{a}$ & $0 \mathrm{e}$ & $0.0 \mathrm{e}$ \\
$\mathrm{T}_{1}=5.00 \%$ & $93.5 \mathrm{~b}$ & $2.5 \mathrm{~d}$ & $1.33 \mathrm{~d}$ \\
$\mathrm{~T}_{2}=10.00 \%$ & $87.0 \mathrm{c}$ & $5.0 \mathrm{c}$ & $2.67 \mathrm{c}$ \\
$\mathrm{T}_{3}=15.00 \%$ & $83.0 \mathrm{~d}$ & $8.0 \mathrm{~b}$ & $3.67 \mathrm{~b}$ \\
$\mathrm{~T}_{4}=20.00 \%$ & $77.0 \mathrm{e}$ & $12.33 \mathrm{ab}$ & $4.0 \mathrm{a}$ \\
$\mathrm{T}_{5}=25.00 \%$ & $70.0 \mathrm{f}$ & $13.33 \mathrm{a}$ & $4.67 \mathrm{a}$ \\
\hline
\end{tabular}

Figures in a column followed by different letters differ significantly, whereas the common letter (s) do not differ significantly at $5 \%$ level of significance

Table 02. Effect of initial seed borne infection of Colletotrichum corchori on germination failure, infected seedlings and total dead seeds of CVL-1

\begin{tabular}{cccc}
\hline $\begin{array}{c}\text { Initial seed borne infection } \\
\text { of } C \text {. corchori }\end{array}$ & $\begin{array}{c}\text { \% germination } \\
\text { failure/dead seeds }\end{array}$ & $\begin{array}{c}\text { \% Infected } \\
\text { seedlings }\end{array}$ & $\begin{array}{c}\text { \% Total dead seeds } \\
\text { (Pre and Post emergence) }\end{array}$ \\
\hline $\mathrm{T}_{0}=0.00 \%$ & $2.0 \mathrm{bc}$ & $0.0 \mathrm{~d}$ & $0.0 \mathrm{e}$ \\
$\mathrm{T}_{1}=5.00 \%$ & $1.50 \mathrm{c}$ & $1.17 \mathrm{c}$ & $3.83 \mathrm{~d}$ \\
$\mathrm{~T}_{2}=10.00 \%$ & $1.50 \mathrm{c}$ & $2.33 \mathrm{bc}$ & $7.67 \mathrm{c}$ \\
$\mathrm{T}_{3}=15.00 \%$ & $2.0 \mathrm{bc}$ & $3.33 \mathrm{~b}$ & $11.67 \mathrm{~b}$ \\
$\mathrm{~T}_{4}=20.00 \%$ & $3.0 \mathrm{~b}$ & $3.67 \mathrm{~b}$ & $16.33 \mathrm{ab}$ \\
$\mathrm{T}_{5}=25.00 \%$ & $5.0 \mathrm{a}$ & $7.0 \mathrm{a}$ & $18.0 \mathrm{a}$ \\
\hline
\end{tabular}

Figures in a column followed by different letters differ significantly, whereas the common letter (s) do not differ significantly at $5 \%$ level of significance

Table 03. Effect of initial seed borne infection of Colletotrichum corchori on seed yield parameters of CVL-1

\begin{tabular}{cccc}
\hline Initial seed borne infection of $C$ & \multicolumn{3}{c}{ Mean seed yield parameters of CVL-1 } \\
\cline { 2 - 4 } corchori & No. of plants/pot & No. of pods/pot & No. of pods/plant \\
\hline $\mathrm{T}_{0}=0.00 \%$ & $24.25 \mathrm{a}$ & $704.50 \mathrm{a}$ & $29.70 \mathrm{a}$ \\
$\mathrm{T}_{1}=5.00 \%$ & $22.13 \mathrm{~b}$ & $613.88 \mathrm{~b}$ & $27.77 \mathrm{~b}$ \\
$\mathrm{~T}_{2}=10.00 \%$ & $20.63 \mathrm{c}$ & $484.50 \mathrm{c}$ & $23.57 \mathrm{c}$ \\
$\mathrm{T}_{3}=15.00 \%$ & $18.50 \mathrm{~d}$ & $375.88 \mathrm{~d}$ & $20.45 \mathrm{~d}$ \\
$\mathrm{~T}_{4}=20.00 \%$ & $16.00 \mathrm{e}$ & $337.50 \mathrm{e}$ & $20.00 \mathrm{~d}$ \\
$\mathrm{~T}_{5}=25.00 \%$ & $14.33 \mathrm{f}$ & $293.25 \mathrm{f}$ & $18.41 \mathrm{e}$ \\
\hline
\end{tabular}

Figures in a column followed by different letters differ significantly, whereas the common letter (s) do not differ significantly at $5 \%$ level of significance

Table 04. Effect of initial seed borne infection of Colletotrichum corchori on seeds/pod and seeds/plant of CVL-1

\begin{tabular}{ccccc}
\hline \multirow{2}{*}{$\begin{array}{c}\text { Initial seed borne } \\
\text { infection of } \text { C. corchori }\end{array}$} & \begin{tabular}{c} 
No. of \\
\cline { 2 - 3 }
\end{tabular} & $\begin{array}{c}\text { Seeds/pod yield parameters of CVL-1 } \\
\text { s reduction of } \\
\text { seeds/pod }\end{array}$ & $\begin{array}{c}\text { No. of } \\
\text { seeds/plant }\end{array}$ & $\begin{array}{c}\text { \% reduction of } \\
\text { seeds/plant }\end{array}$ \\
\cline { 2 - 3 } $\mathrm{T}_{0}=0.00 \%$ & $45.58 \mathrm{a}$ & & $1323.22 \mathrm{a}$ & \\
$\mathrm{T}_{1}=5.00 \%$ & $40.96 \mathrm{~b}$ & $10.14 \mathrm{e}$ & $1131.47 \mathrm{~b}$ & $14.49 \mathrm{e}$ \\
$\mathrm{T}_{2}=10.00 \%$ & $37.59 \mathrm{c}$ & $17.53 \mathrm{~d}$ & $881.58 \mathrm{c}$ & $33.38 \mathrm{~d}$ \\
$\mathrm{~T}_{3}=15.00 \%$ & $34.84 \mathrm{~d}$ & $23.56 \mathrm{c}$ & $710.62 \mathrm{~d}$ & $46.30 \mathrm{c}$ \\
$\mathrm{T}_{4}=20.00 \%$ & $30.70 \mathrm{e}$ & $32.65 \mathrm{~b}$ & $609.00 \mathrm{e}$ & $53.98 \mathrm{~b}$ \\
$\mathrm{~T}_{5}=25.00 \%$ & $25.81 \mathrm{f}$ & $43.37 \mathrm{a}$ & $472.53 \mathrm{f}$ & $64.29 \mathrm{a}$ \\
\hline
\end{tabular}

Figures in a column followed by different letters differ significantly, whereas the common letter (s) do not differ significantly at $5 \%$ level of significance 
Table 05. Effect of initial seed borne infection of $C$. corchori on quality of the harvested seeds of CVL-1

\begin{tabular}{cccccccc}
\hline Initial level of seed & \multicolumn{7}{c}{ Pathogen } \\
\cline { 2 - 8 } $\begin{array}{c}\text {-borne infection } \\
\text { of } \text { C. corchori }\end{array}$ & C. c & M.p & B.t. & $\begin{array}{c}\text { Fusarium } \\
\text { spp. }\end{array}$ & $\begin{array}{c}\text { Aspergillus } \\
\text { spp. }\end{array}$ & $\begin{array}{c}\text { Penicillium } \\
\text { spp. }\end{array}$ & \multirow{2}{*}{ Total } \\
\hline T0 $=0.00 \%$ & $0.00 \mathrm{f}$ & $0.00 \mathrm{~d}$ & $0.00 \mathrm{c}$ & $3.33 \mathrm{e}$ & $2.00 \mathrm{~d}$ & $1.33 \mathrm{bc}$ & $6.66 \mathrm{e}$ \\
$\mathrm{T} 1=5.00 \%$ & $3.33 \mathrm{e}$ & $0.00 \mathrm{~d}$ & $0.00 \mathrm{c}$ & $4.50 \mathrm{~d}$ & $3.33 \mathrm{c}$ & $2.50 \mathrm{~b}$ & $13.66 \mathrm{~d}$ \\
$\mathrm{~T} 2=10.00 \%$ & $7.67 \mathrm{~d}$ & $3.33 \mathrm{c}$ & $2.33 \mathrm{ab}$ & $6.67 \mathrm{bc}$ & $4.33 \mathrm{bc}$ & $0.00 \mathrm{~d}$ & $24.33 \mathrm{c}$ \\
$\mathrm{T} 3=15.00 \%$ & $12.00 \mathrm{c}$ & $0.00 \mathrm{~d}$ & $1.67 \mathrm{~b}$ & $7.00 \mathrm{~b}$ & $5.67 \mathrm{ab}$ & $1.33 \mathrm{bc}$ & $27.67 \mathrm{c}$ \\
$\mathrm{T} 4=20.00 \%$ & $16.67 \mathrm{~b}$ & $4.67 \mathrm{~b}$ & $3.33 \mathrm{a}$ & $5.33 \mathrm{c}$ & $6.33 \mathrm{a}$ & $4.33 \mathrm{ab}$ & $40.66 \mathrm{~b}$ \\
$\mathrm{~T} 5=25.00 \%$ & $22.00 \mathrm{a}$ & $5.33 \mathrm{a}$ & $6.67 \mathrm{a}$ & $9.67 \mathrm{a}$ & $3.33 \mathrm{c}$ & $6.67 \mathrm{a}$ & $53.67 \mathrm{a}$ \\
\hline
\end{tabular}

Figures in a column followed by different letters differ significantly, whereas the common letter (s) do not differ significantly at $5 \%$ level of significance

\section{Relationship of initial seed borne infection of $C$. corchori and seed yield parameters of the harvested seeds}

There were negative relationships between seed yield parameters of the harvested seeds of CVL-1 produced in Greenhouse with initial seed borne infection of C. corchori and (Graph. 1, 2, 3 and 4). It is evident that the regression coefficients for \% germination, plants/pot, seeds/pod and seeds/plant were $-1.048,-0.403,-0.756$ and -34.24 , respectively which indicate that germination, plants/pot, seeds/pod and seeds/plant decreased by $1.048 \%, 0.403 \%, 0.756 \%$ and $34.24 \%$, respectively for each $\%$ increase of initial seed borne infection of $C$. corchori. Sultana et al. (2007) reported that the highest germination was found in $0.00 \%$ and the lowest germination was recorded in case of using $20.00 \%$ initial seed borne fungal infection. They also reported that seeds having higher seed borne infections caused significantly higher amount of disease development in the field. Haque et al. (1999) also reported that there was a negative relationship between $\%$ germination and $\%$ total pathogens and the rate of seed germination decreased with the increase of increase of initial seed borne infections.

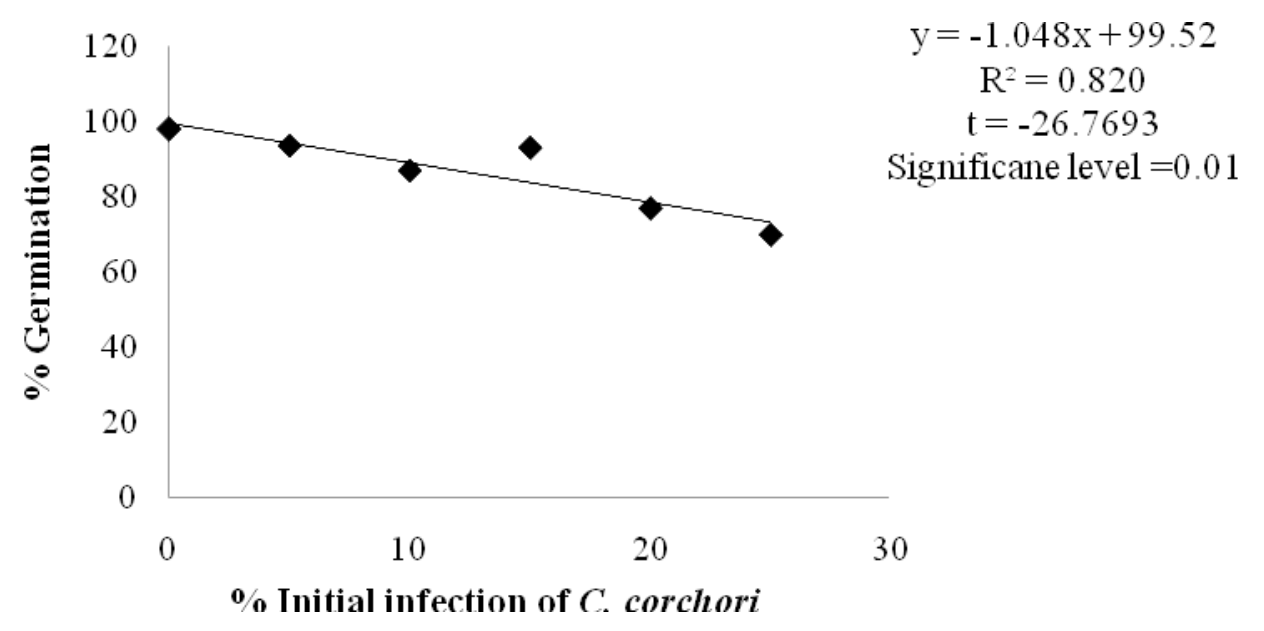

Graph 01. Relationship of initial seed borne infection of $C$. corchori and germination of jute seeds 


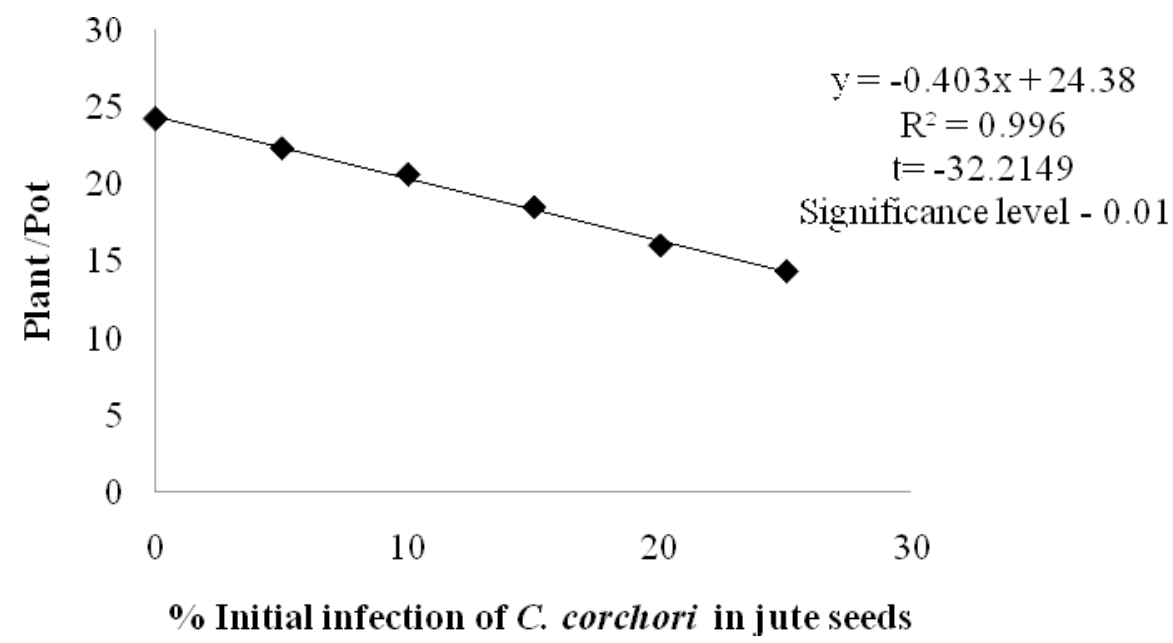

Graph 02. Relationship of initial seed borne infection of Colletotrichum corchori and plant/pot

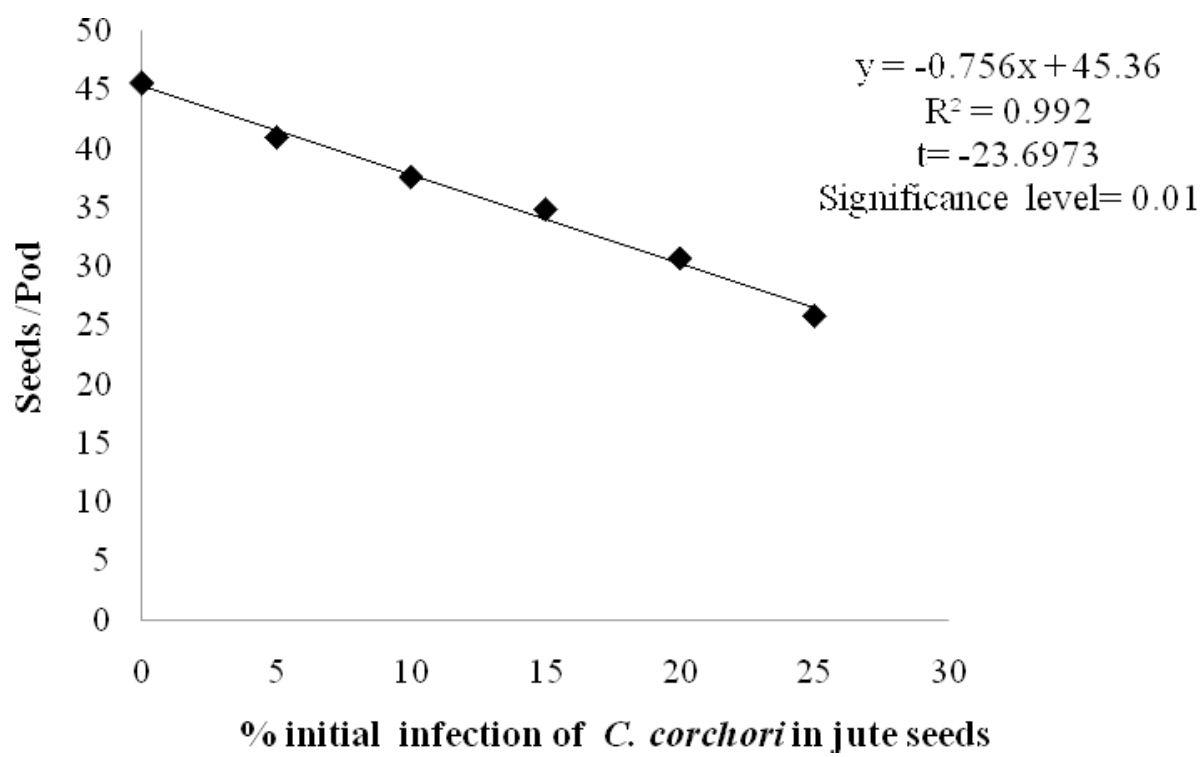

Graph 03. Relationship of initial \% Colletotrichum corchori and seeds per pod

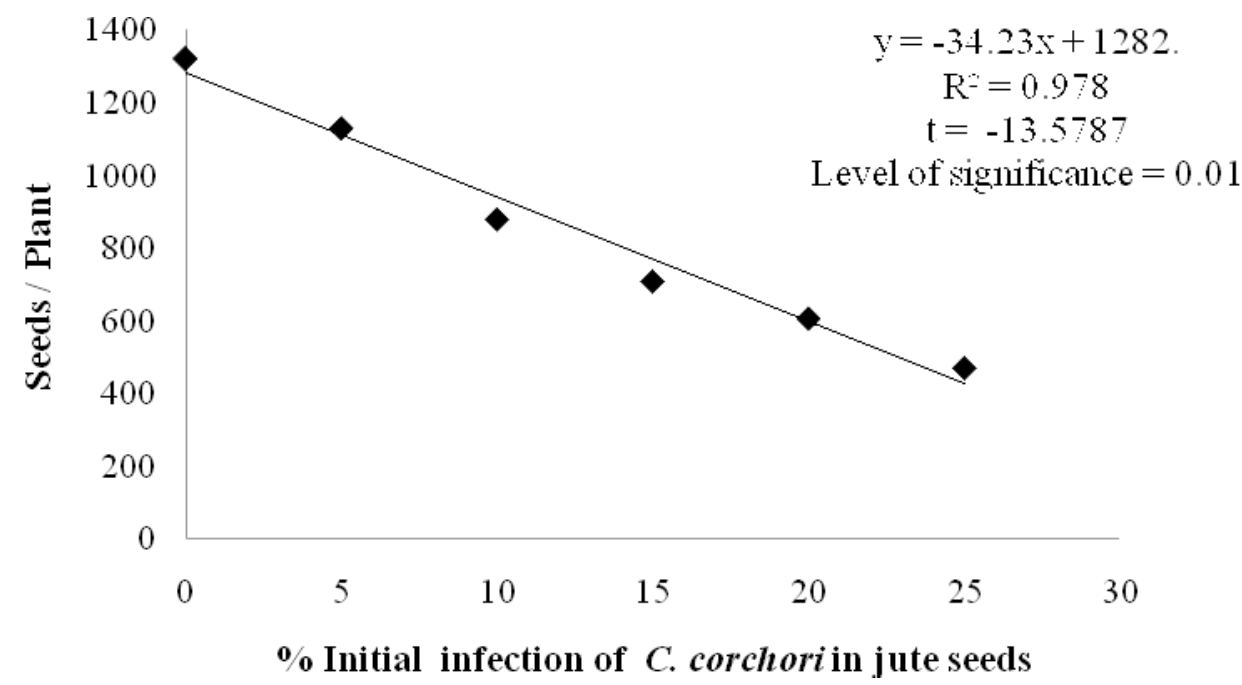

Graph 04. Relationship of initial \% Colletotrichum corchori and seeds per plant 
Relationship of initial seed borne infection of $C$. corchori with infected seedling and total dead seed

Relationship of \% infected seedlings and total dead seeds in green house were positively related with the initial seed borne infections of $C$. corchori and the regression coefficients were 0.248 and 0.751 , respectively which indicate that the rate of increase of \% infected seedlings increased by $0.248 \%$ and total dead seeds increased by 0.751 and for every 1\% increase of initial seed borne infection of $C$. corchori (Graph 5 and 6). Fakir et al., (1993) reported that the higher the seed-borne infection of the fungal pathogens, higher the disease development in the field which supports the present study.

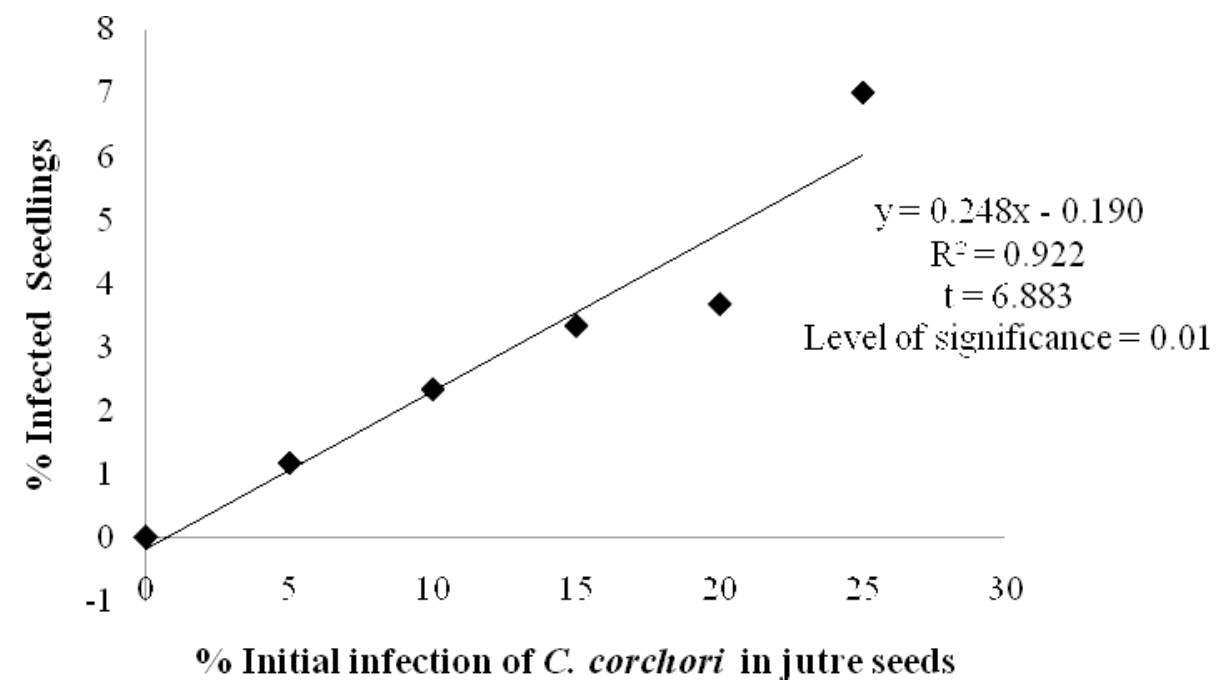

Graph 05. Relationship of initial seed borne infection of Colletotrichum corchori and \% infected seedlings due to $C$. corchori

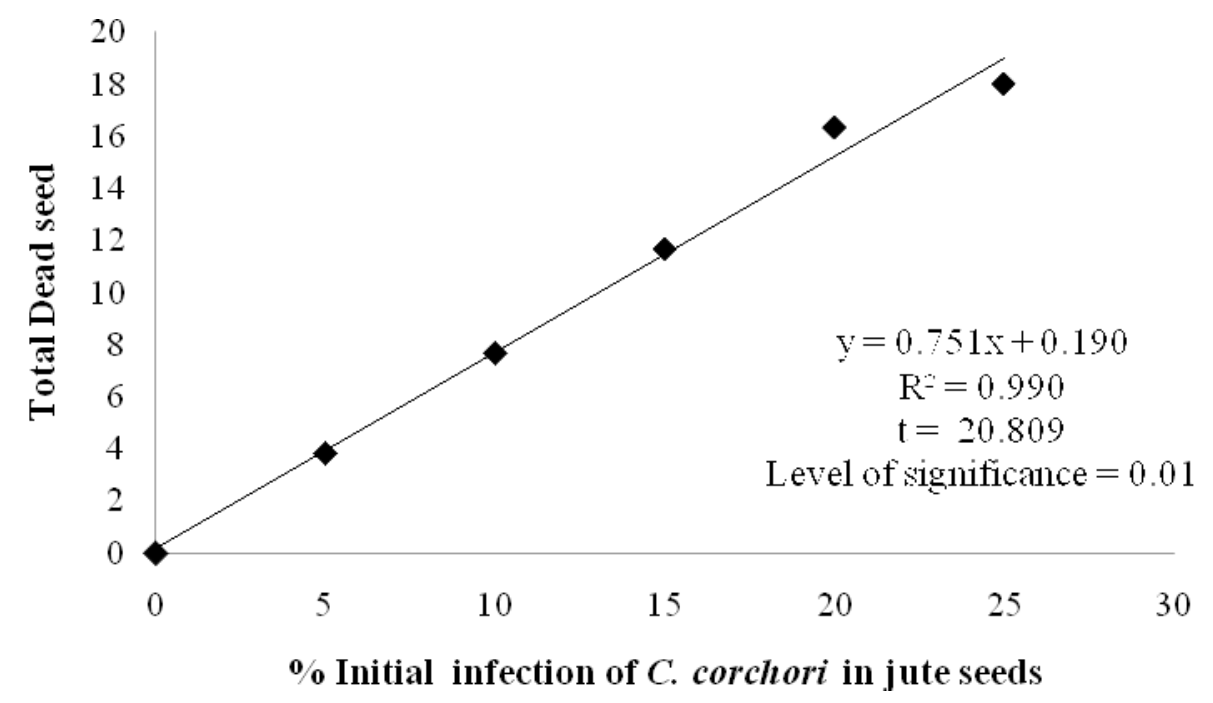

\section{Graph 06. Relationship of initial seed borne infection of Colletotrichum corchori and total dead seeds due to Colletotrichum corchori}

\section{Conclusion}

Findings reveal that different seed yield parameters, viz. germination, pre emergence death of the seedlings, seedling infection/post emergence death, germination failure/dead seeds, no. of plants/pot, no. of pods/pot, no. of pods/pot, no. of seeds/pod, no. of seeds/plant were reduced with the increase of initial seed borne infection of $C$. corchori. On the other hand, seed borne infection with $C$. corchori in harvested seeds increased with the increase of initial seed borne infection of $C$. corchori. Moreover, 
germination, plants/pot, seeds/pod and seeds/plant decreased by $1.048 \%, 0.403 \%, 0.756 \%$ and $34.24 \%$, respectively for increase of every $1 \%$ initial seed borne infection of $C$. corchori. Relationship of $\%$ infected seedlings and total dead seeds in green house were positively related with the initial seed borne infections of $C$. corchori. The rate of increase of infected seedlings increased by $0.248 \%$ and total dead seeds increased by 0.751 and for the increase of every $1 \%$ initial seed borne infection of $C$. corchori. With all these findings it may be concluded that, since, anthracnose of jute caused by fungus Colletotrichum corchori is a seed borne disease and transmit from seed to plant to seed and consequently hamper the quality and yield of fibre and affect the seed quality and seed yield as well and thus necessary precautions should be taken before sowing and after germination of the seeds to produce higher yield and quality jute seed and fibre.

\section{References}

[1]. Ahmed, Q. A. (1966). Problems in jute plant pathology. Jute and Jute fabrics Pakistan, July: 184186.

[2]. Alam, S., Begum, H.A. and Sultana, K. (1992). Pathological disease of jute, mesta and kenafand their control measure. Jute and Jute fabrics, Newsletter of BJRI 18(2): 7-10.

[3]. Atwal, A. S. (1976). Agricultural pests of India and South East Asia. Kalyani Publishers, Delhi. 502

[4]. Biswas , A.C., M. A. Taher, M. Asaduzzaman, K. Sultana and A. K. M. Eshaque. (1985). Loss of yield and quality of fibre due to prevalence of stem-rot. Bangladesh J. Pl. Pathol. 1: 61-62.

[5]. Ellis, M. B. (1993). Demataceous hyphomycetes. CAB. International Wallingford Oxen. 0X10BDE UK. pp. 95-98.

[6]. Fakir, G. A. (2000). List of seed borne diseases of important crops occurring in Bangladesh. Seed Paththology Laboratory, Dept. Plant Path. BAU, Mymensingh. pp.7-8.

[7]. Fakir, G. A., M. A. Sarder, A. Gaffar and M. U. Ahmad. (1991). An annotated list of important diseases of important crop plants of Bangladesh. Pl. Quarantine Rev. Prog. Sponsored by the ministry of Agriculture in coordination with CIDA and DANIDA. P. 107.

[8]. Fakir, G. A., M. R. Islam and F. Islam. (1993). Transmission of three major seed-borne fungal pathogens from seed to plant to seed in jute Corchorus capsularis L.) Abstr. Progress in Plant Pathology. Proceedings of the 5th Biennial Conf. of Bangladesh Phytopathol. Soc. p.87.

[9]. Fakir, G. A., M. R. Islam and M.F. Islam. (1990). Survey on the health status of jute and rice seeds of farmers of Sadar Thana, Mymensingh, Proc. BAU. Res. 4: 42-47.

[10]. Ferdous, S. (2013). Jute Matters. Monthly Publication. IJSG Dhaka. 1(2): 1.

[11]. Gomez, K. A. and A. A. Gomez. (1984). Statistical procedure of agricultural research. Intl. Rice Res. Inst. Manila, Philippines.

[12]. Haider, M. R., J. Begum and M. N. Anwar. (1992). Mycoflora associated with jute seeds collected from five districts of Bangladesh. Chittagong Univ. Study Part II. 16 (1): 61- 69.

[13]. Haque, M. M., K. Sultana and G. A. Fakir. (1999). Prevalence of major fungal pathogens in breeder seed, foundation seed, certified seed and farmers' seed of jute. Collaborative Research Report (BJRI and SPL). pp. 11-16.

[14]. Ikata, N. and M. Yoshida. (1940). A new anthracnose of jute plant. Ann. Phytopath. Soc. Japan, 10: 141-149.

[15]. Islam, M. M. (2006). Effect of sowing methods, seed and foliar treatment on the production of quality jute seeds. A Ph.D. thesis. Department of Plant pathology, Bangladesh Agricultural University, Mymensingh.

[16]. Islam, M. M., K. Sultana, M. M. Hussain, M. G. Mostafa, M. R. Islam, M. L. Rahman and M. A. Kashem, (2003). Inoculation Times with Strains of Macrophomina phaseolina and Colletotrichum corchori on the Seed Yield Contributing Characters of Late Jute Seeds. Plant Pathology Journal 2: 21-27.

[17]. ISTA. (1999). International Rules for Seed Testing, International Seed Testing Association, Seed Sci \& technol, Zurich, Switzerland. P.333.

[18]. Khan, S. R. and Strange, R. N. (1975). Evidence of the role of a fungus stimulant as a determinant of different susceptibility of jute cultivars to Colletrotrichum corchori. Physiological Plant Pathology 5:157-164. 
[19]. Mathur, S. B. and O. Kongsdal. (2003). Common Laboratory Seed Health Testing Methods for detecting fungi. DGISP for developing countries, Thorvaldsanvej 57, DK-1871 Frederiksberg, Copenhagen, Denmark.

[20]. Sultana, K., S. M. A. Haque, H. Banu, H. Q. M. Mosaddeque and M. S. Polan. (2007). Study on Transmission of Seed Borne Fungal Pathogens of Jute (Corchorus Capsularis) at Different Rate of Seed Infections. G-Science Publication 3(4): 46-49.

[21]. Wikipedia the Free Encyclopedia (2011). Jute. http://en.wikipedia.org/wiki/Jute. [Date of access May 12, 2012] 